\title{
Novel texturing method for sputtered zinc oxide films prepared at high deposition rate from ceramic tube targets
}

\author{
E. Bunte, H. Zhu, J. Hüpkes ${ }^{\mathrm{a}}$, and J. Owen \\ Institut für Energie- und Klimaforschung, IEK5-Photovoltaik, Forschungszentrum Jülich GmbH, 52425 Jülich, Germany
}

Received: 2 March 2011 / Accepted: 22 June 2011

Published online: 6 October 2011

\begin{abstract}
Sputtered and wet-chemically texture etched zinc oxide $(\mathrm{ZnO})$ films on glass substrates are regularly applied as transparent front contact in silicon based thin film solar cells. In this study, chemical wet etching in diluted hydrofluoric acid ( $\mathrm{HF})$ and subsequently in diluted hydrochloric acid $(\mathrm{HCl})$ on aluminum doped zinc oxide ( $\mathrm{ZnO}: \mathrm{Al})$ films deposited by magnetron sputtering from ceramic tube targets at high discharge power $(\sim 10 \mathrm{~kW} / \mathrm{m}$ target length) is investigated. Films with thickness of around $800 \mathrm{~nm}$ were etched in diluted $\mathrm{HCl}$ acid and $\mathrm{HF}$ acid to achieve rough surface textures. It is found that the etching of the films in both etchants leads to different surface textures. A two steps etching process, which is especially favorable for films prepared at high deposition rate, was systematically studied. By etching first in diluted hydrofluoric acid ( $\mathrm{HF})$ and subsequently in diluted hydrochloric acid $(\mathrm{HCl})$ these films are furnished with a surface texture which is characterized by craters with typical diameter of around 500-1000 nm. The resulting surface structure is comparable to etched films sputtered at low deposition rate, which had been demonstrated to be able to achieve high efficiencies in silicon thin film solar cells.
\end{abstract}

\section{Introduction}

Transparent conducting oxide (TCO) films are the base for a wide range of sophisticated applications such as organic light-emitting diodes [1-3], flat panel displays $[4,5]$, and thin-film solar cells $[6,7]$ etc. Nowadays aluminium doped zinc oxide ( $\mathrm{ZnO}: \mathrm{Al})$ films are becoming increasingly popular as contact and window layer, especially in the field of thin-film photovoltaics. Rough and light scattering surfaces are beneficial for the so-called light-trapping effect in thin-film silicon solar cells and lead to an increase of the conversion efficiency [8-13]. Commonly, the sputtering conditions for sputtered $\mathrm{ZnO}: \mathrm{Al}$ films are optimized to tune the etching behaviours and to obtain adapted light scattering properties $[10,14,15]$. These surfaces exhibit regularly distributed craters with typical diameter of $1-2 \mu \mathrm{m}$ and depth of several $100 \mathrm{~nm}$. The typical root mean square (RMS) roughness of these films is $110-150 \mathrm{~nm}$. Applying these films as substrate in microcrystalline silicon $(\mu \mathrm{c}-\mathrm{Si}: \mathrm{H})$ thin film solar cells leads to an increase in photocurrent compared to the solar cells with smooth $\mathrm{ZnO}: \mathrm{Al}$ as front contact. However, the deposition rate of the best lab-type radio frequency $(\mathrm{RF})$ sputtering process is too low for industrial production of $\mathrm{ZnO}$ :Al films. Mid-frequency (MF) sputtering from rotatable dual magnetrons (RDM) may produce $\mathrm{ZnO} \mathrm{O}$ Al films at deposition rates of more than $100 \mathrm{~nm} \cdot \mathrm{m} / \mathrm{min}[16,17]$. However, the high rate sputtered $\mathrm{ZnO}: \mathrm{Al}$ films usually exhibit sporadic craters on the surfaces after etching in

a e-mail: j.huepkes@fz-juelich.de diluted hydrochloric acid $(\mathrm{HCl})$ and the light scattering is inferior $[16,17]$. In this contribution, we systematically study the influence of different etching methods, which include etching in diluted hydrofluoric acid (HF) and diluted $\mathrm{HCl}$ as well as combined two-step etching method in both etchants, on $\mathrm{ZnO}: \mathrm{Al}$ films sputtered at high discharge power and different substrate temperatures. It was found that $\mathrm{ZnO}$ :Al films etched in $\mathrm{HF}$ show rather sharp features [18]. This may reduce the fill factor and thus, the efficiency of silicon based thin-film solar cells. In order to smoothen the sharp features and widen the craters, after the initial HF etching step a second etching step in $\mathrm{HCl}$ was carried out. Electrical and optical properties as well as the resulting surface topographies are investigated and discussed in detail for high rate films in particular deposited at $350{ }^{\circ} \mathrm{C}$. Due to their low sheet resistance $\mathrm{ZnO}: \mathrm{Al}$ films deposited at high temperature $\left(>300{ }^{\circ} \mathrm{C}\right)$ are relevant for solar cells.

\section{Experimental details}

ZnO:Al films were prepared on Corning glass substrates (Corning, Eagle XG) in an in-line sputtering system (VISS 300 by Von Ardenne Anlagentechnik, Dresden, Germany). Rotatable dual magnetrons (RDM) with $\mathrm{ZnO}: \mathrm{Al}_{2} \mathrm{O}_{3}$ (99.5:0.5 wt\%) ceramic tube targets $(750 \mathrm{~mm}$ length) were mounted in the deposition chamber. The sputtering process was operated under mid-frequency excitation at a frequency of $40 \mathrm{kHz}$. The substrate temperature was varied between $250{ }^{\circ} \mathrm{C}$ and $350{ }^{\circ} \mathrm{C}$ as measured 




Fig. 1. Electrical properties of high rate $\mathrm{ZnO}$ :Al films deposited at different substrate temperatures.

by pyrometers prior to deposition. The applied discharge power was $14 \mathrm{~kW}$ and the working pressure was $2.0 \mathrm{~Pa}$. The texturing of the as-deposited flat $\mathrm{ZnO}$ films (RMS roughness $<10 \mathrm{~nm}$ ) was carried out by wet chemical etching in diluted hydrochloric $(\mathrm{HCl})$ and hydrofluoric $(\mathrm{HF})$ acid. The concentrations were $0.5 \mathrm{wt} \%$ and $1 \mathrm{wt} \%$, respectively. The etching time is $50 \mathrm{~s}$ for all films etched in $\mathrm{HCl}$ or HF solutions, if no other duration is given. Thickness before and after etching was measured by surface profiler (Dektak 3030, by Veeco Instruments).

The electrical properties of etched $\mathrm{ZnO}: \mathrm{Al}$ thin films were characterized by four point probe as well as Hall effect measurements. Diffuse and total transmissions of surface textured films were measured by a double beam spectrometer with an integrating sphere (Perkin Elmer Lambda 19). The topographies of the samples were investigated by scanning electron microscopy (SEM, Supra 55VP SmartSEMTM, Carl Zeiss,Germany) and atomic force microscopy (AFM, Nanoscope system from Veeco as well as Surface Imaging System (SIS), Nano Station 300).

\section{Results and discussion}

\subsection{Electrical properties}

$\mathrm{ZnO}: \mathrm{Al}$ films were sputtered at a high discharge power of $14 \mathrm{~kW}$ and the substrate temperature was varied between $250{ }^{\circ} \mathrm{C}$ and $350{ }^{\circ} \mathrm{C}$ as temperature is an important parameter to control material properties and etching behavior of $\mathrm{ZnO}: \mathrm{Al}$ films [10]. Figure 1 shows the specific resistivity $(\rho)$, carrier concentration $(n)$ and carrier mobility $(\mu)$ as a function of the substrate temperature. As found in previous studies [7], with increasing substrate temperature the resistivity of the $\mathrm{ZnO}: \mathrm{Al}$ films decreases. Here it drops from $2.2 \times 10^{-3} \Omega \mathrm{cm}$ to $4 \times 10^{-4} \Omega \mathrm{cm}$ and the carrier mobility increases from $14 \mathrm{~cm}^{2} / \mathrm{Vs}$ to about $44 \mathrm{~cm}^{2} / \mathrm{Vs}$. The carrier concentration first increases with temperature to a plateau value of about of $3.3 \times 10^{20} \mathrm{~cm}^{-3}$ for films

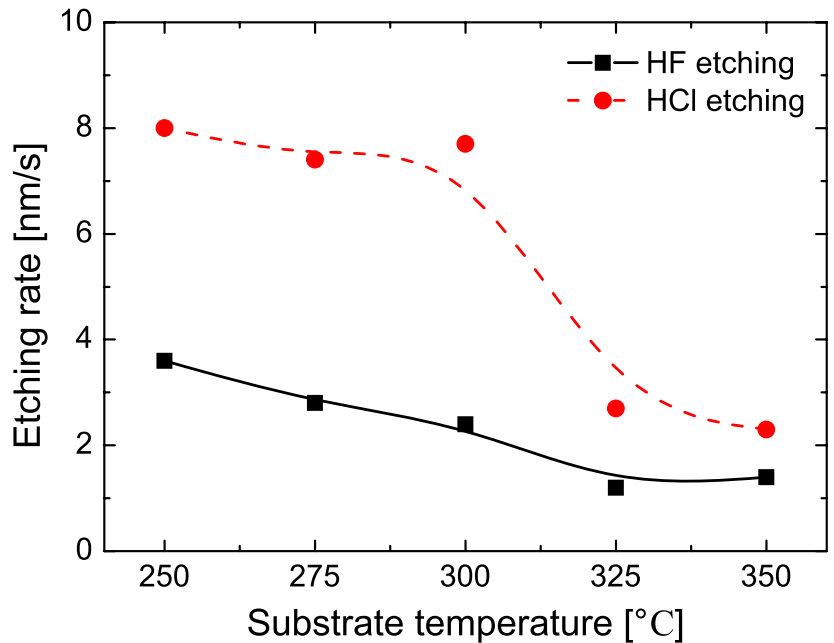

Fig. 2. Dependence of etching rate of high rate $\mathrm{ZnO}$ : Al films in $\mathrm{HF}$ etchant and $\mathrm{HCl}$ etchant on deposited substrate temperatures.

deposited at $300{ }^{\circ} \mathrm{C}$ or above. The increase of carrier concentration with substrate temperature is explained by an improved integration of aluminum into the $\mathrm{ZnO}$ crystal. At very high substrate temperatures this effect might be compensated by desorption of zinc atoms $[19,20]$. The carrier mobility in sputtered $\mathrm{ZnO}$ : $\mathrm{Al}$ films is affected mainly by scattering at the grain boundaries [21-24] and impurity atoms [19, 25-27]. Here we consider mainly a decrease in the first scattering mechanism, as we observe an improved mobility in coincidence with higher carrier density $[28,29]$.

\subsection{Etching behaviours of $\mathrm{ZnO}: \mathrm{Al}$ in acids}

\section{A. Comparison of $\mathrm{HCl}$ etching and $\mathrm{HF}$ etching}

Figure 2 shows etching rates of high rate $\mathrm{ZnO}$ : Al films deposited at different substrate temperatures and then 




Fig. 3. The surface structures of films deposited at different substrate temperatures after etching in diluted HF solution (1\%): (a) $350{ }^{\circ} \mathrm{C}$, (b) $325{ }^{\circ} \mathrm{C}$, (c) $300{ }^{\circ} \mathrm{C}$, (d) $275{ }^{\circ} \mathrm{C}$, (e) $250{ }^{\circ} \mathrm{C}$ as well as etching in diluted $\mathrm{HCl}$ solution (0.5\%), (f) $350{ }^{\circ} \mathrm{C}$, (g) $325{ }^{\circ} \mathrm{C}$, (h) $300{ }^{\circ} \mathrm{C}$, (i) $275{ }^{\circ} \mathrm{C}$, (j) $250{ }^{\circ} \mathrm{C}$.

etched in diluted $\mathrm{HF}$ solution and $\mathrm{HCl}$ solution, respectively. The etching rate of films decreases with rising substrate temperature for both etching methods. For HF etching method, the etching rate decreases from $3.6 \mathrm{~nm} / \mathrm{s}$ to $1.5 \mathrm{~nm} / \mathrm{s}$ with the increasing substrate temperature from $250{ }^{\circ} \mathrm{C}$ to $350{ }^{\circ} \mathrm{C}$. For $\mathrm{HCl}$ etching method, the etching rate decreases in the same way from $8 \mathrm{~nm} / \mathrm{s}$ to $2.3 \mathrm{~nm} / \mathrm{s}$. The reduction in etch rate at high substrate temperatures may be due to the fact that $\mathrm{ZnO}$ :Al films become much more compact by atoms with large diffusion energy at high substrate temperatures [15]. Etching rate in $\mathrm{HF}$ is almost a factor of two lower than that in $\mathrm{HCl}$ even though the concentration of HF is a factor of two higher than that of $\mathrm{HCl} . \mathrm{HCl}$ is a strong acid while $\mathrm{HF}$ is a weak acid. In general, $\mathrm{HCl}$ would be completely dissociated into $\mathrm{H}^{+}$and $\mathrm{Cl}^{-}$. Only a very small fraction of $\mathrm{HF}$ molecules are dissociated. The dissociation constant $\mathrm{K}_{\alpha}$ of $\mathrm{HF}$ at room temperature is only in the range of $6-7.5 \times 10^{-4}$ while $\mathrm{HCl}$ dissociates nearly completely [30]. This means, that
$1 \% \mathrm{HF}$ etches slower than $0.5 \% \mathrm{HCl}$ due to the lower $\mathrm{pH}$ value of the $\mathrm{HF}$ solution.

Figure 3 shows the SEM micrographs of the corresponding surface topographies: (a)-(e) after etching in $\mathrm{HF}(1 \mathrm{wt} \%),(\mathrm{f})-(\mathrm{j})$ after etching in $\mathrm{HCl}(0.5 \mathrm{wt} \%)$. The latter topographies of films prepared at high temperatures $\left(350{ }^{\circ} \mathrm{C}\right.$ and $\left.325^{\circ} \mathrm{C}\right)$ show a few wide but shallow craters with diameter of about $1-2 \mu \mathrm{m}$ sporadically distributed on the surfaces as shown in Figure 3(f) and 3(g), respectively. Both surface topographies are similar to type $\mathrm{C}$ that Kluth et al. reported [15]. Microcrystalline silicon solar cells on this kind of substrate typically have good fill factors $(>70 \%)$ but low photocurrents $\left(<20 \mathrm{~mA} / \mathrm{cm}^{2}\right.$ for $1.2 \mu \mathrm{m}$ absorber layer thickness and a $\mathrm{ZnO}: \mathrm{Al} /$ silver back contact) [31]. When a substrate temperature below $325^{\circ} \mathrm{C}$ is applied during the sputtering process, the surface topographies of the etched films are characterized by small features with diameter below $100 \mathrm{~nm}$ (see Fig. 3(h)-3(j)) The height distribution function shows a more or less 
Gaussian shape indicating a statistical rough surface. This topography is similar to type A as presented by Kluth et al. [15]. On type A substrates microcrystalline silicon solar cells usually lead to poor electrical performance [31]. Up to now the best surface topography of $\mathrm{ZnO}$ :Al films realized by sputtering and etching is characterized by regular, wide and deep craters with $1-2 \mu \mathrm{m}$ diameter (denoted as type B by Kluth et al. [15]). Unfortunately, a type B surface has not been achieved only by $\mathrm{HCl}$ etching step on the surfaces of these high deposition rate $\mathrm{ZnO}$ : Al films. In other words, type B surface cannot be realized or at least is very difficult to achieve through changing the main sputtering parameters i.e. substrate temperature and working pressure. According to the Kluth model $[10,15,32]$ we would expect to find type $\mathrm{B}$ in a narrow process window with a substrate temperature between $300^{\circ} \mathrm{C}$ and $325^{\circ} \mathrm{C}$. However, stop-and-go deposition as well as multi-layer formation during dynamic sputtering may complicate or even limit optimization [33-36].

Upon etching in diluted $\mathrm{HF}(1 \mathrm{wt} \%$ ) the $\mathrm{ZnO}: \mathrm{Al}$ film deposited at $350{ }^{\circ} \mathrm{C}$ (see Fig.3(a)) develops a surface texture with small craters characterized by steep edges and the lateral feature size is typically between $200 \mathrm{~nm}$ and $500 \mathrm{~nm}$. With the decrease of substrate temperature, the diameter and depth of these structures gradually decrease (see Fig. 3(b)-3(e)). For substrate temperatures between $300{ }^{\circ} \mathrm{C}$ and $250{ }^{\circ} \mathrm{C}$, the films become relatively flat on the micrometer scale, but the nano-roughness looks similar to those obtained by etching in $\mathrm{HCl}$ as shown in Fig. 3(h)-3(j), even though the features are still smaller. More characteristic properties of the HF etch process and resulting $\mathrm{ZnO}$ :Al films are discussed elsewhere [18].

\section{B. Optical properties}

All films after etching in $\mathrm{HF}$ or $\mathrm{HCl}$ solutions show high average transmission of more than $80 \%$ in the visible spectrum region (not show here). The haze is defined as the ratio of diffuse transmission to total transmission and is used to distinguish the light scattering properties of the various surface topographies. Figure 4 shows haze of the ZnO:Al films after etching in $\mathrm{HF}$ (see Fig. 4(a)) and in $\mathrm{HCl}$ (see Fig. 4(b)).

A trend of increasing haze with higher substrate temperatures was found. The films etched in HF show in principle the same trend; however, the increase of haze with substrate temperature is more pronounced. The increased haze of high rate sputtered films deposited at high substrate temperatures is especially pronounced for wavelengths <600 nm. For $\mathrm{ZnO}$ : Al films deposited at $350{ }^{\circ} \mathrm{C}$ etched in $\mathrm{HF}$ a haze of $37 \%$ at $600 \mathrm{~nm}$ is found. All films etched in $\mathrm{HCl}$ and the $\mathrm{ZnO}: \mathrm{Al}$ films etched in $\mathrm{HF}$ after preparation at low substrate temperature below $300{ }^{\circ} \mathrm{C}$ exhibit only low haze.

\section{High temperature films etched in HF}

To study the evolution of the HF etching process, the ZnO:Al films sputtered at high discharge power of $14 \mathrm{~kW}$
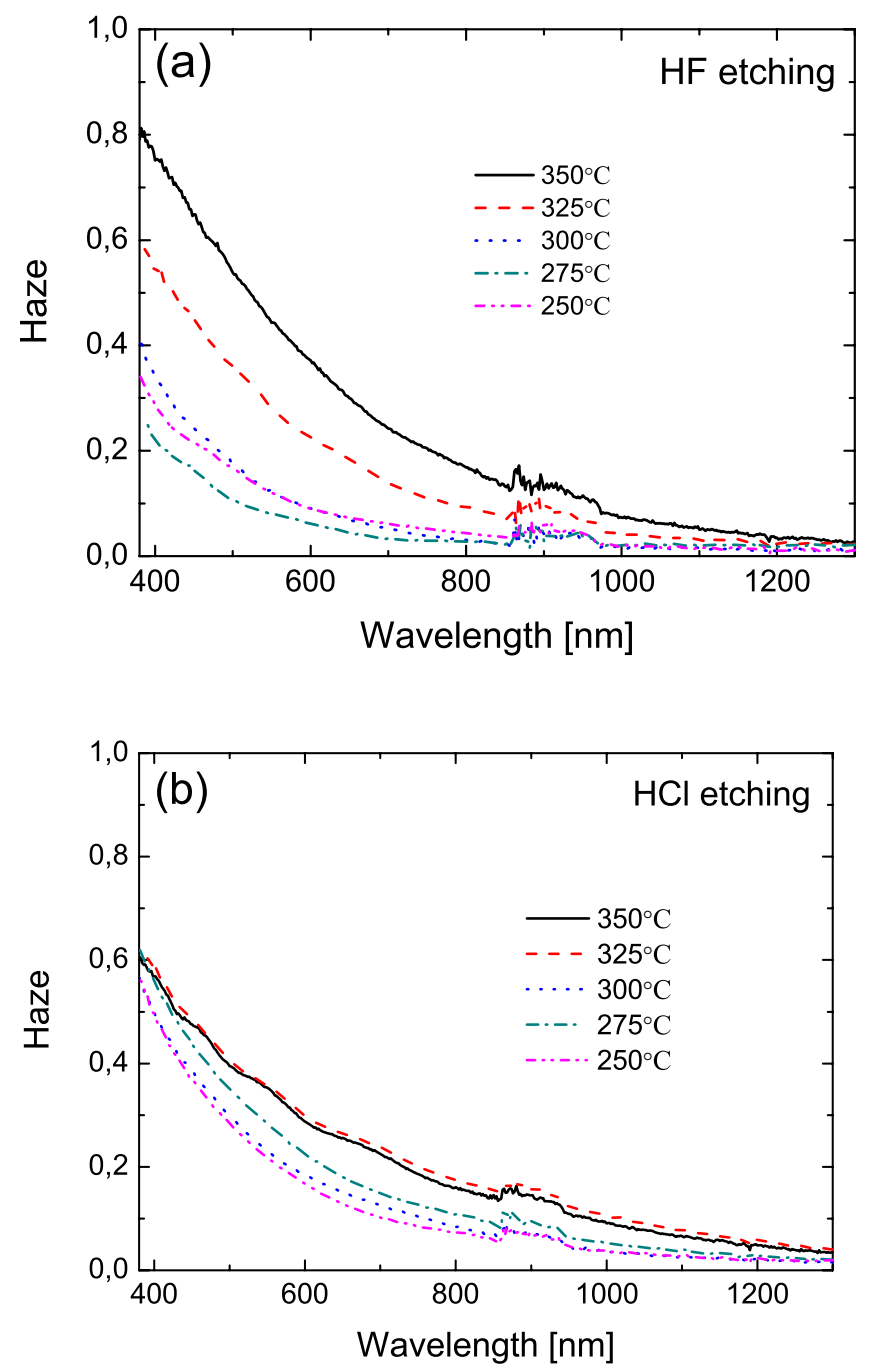

Fig. 4. Spectral haze of high rate $\mathrm{ZnO}$ :Al films deposited at various temperature and etched in $\mathrm{HF}$ etchant (a) and in $\mathrm{HCl}$ etchant (b).

and a substrate temperature of $350{ }^{\circ} \mathrm{C}$ were etched in $1 \% \mathrm{HF}$ solution for different durations between $0 \mathrm{~s}$ and 180 s. Figures $5(\mathrm{a})-5(\mathrm{f})$ exhibit the surface structures after etching for $0 \mathrm{~s}, 60 \mathrm{~s}, 90 \mathrm{~s}, 120 \mathrm{~s}$ and $180 \mathrm{~s}$, respectively, which were obtained by AFM measurements. By prolonging etching duration the feature size of the structures increases from typical diameters of around $100 \mathrm{~nm}$ for $60 \mathrm{~s}$ etching time (compare Fig. 5(b)) to $500 \mathrm{~nm}$ for $180 \mathrm{~s}$ (Fig. 5(f)). In parallel to the increase of the lateral feature size the vertical feature size increases. The RMS roughness derived from the AFM measurements increases almost linearly from $\sim 10 \mathrm{~nm}$ for the unetched sample to $80 \mathrm{~nm}$ for the longest etching time (not show here). As already seen in Figure 3(a), films deposited at high rate and high temperature show a surface texture with rather steep edges after etching in HF. This observation is also valid for longer etching duration. Regardless of the increase of the lateral and vertical feature size with etching duration all investigated samples exhibit surfaces with sharp features. 
(a)

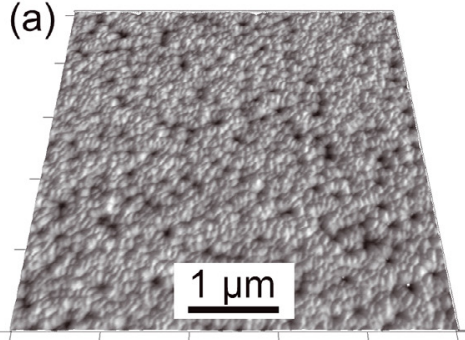

(d)

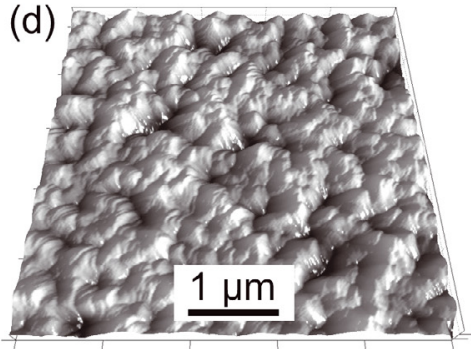

(b)



(e)

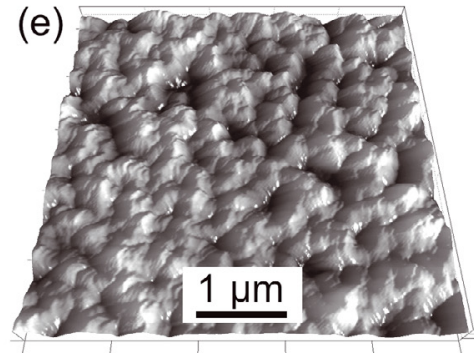

(c)



(f)



Fig. 5. AFM images of etch evolution upon $\mathrm{HF}$ etching for $\mathrm{ZnO}: \mathrm{Al}$ film deposited at $350{ }^{\circ} \mathrm{C}$. AFM images correspond to different etching time in diluted HF solution: (a) $0 \mathrm{~s}$, (b) $60 \mathrm{~s}$, (c) $90 \mathrm{~s}$, (d) $120 \mathrm{~s}$, (e) $150 \mathrm{~s}$, (f) $180 \mathrm{~s}$.

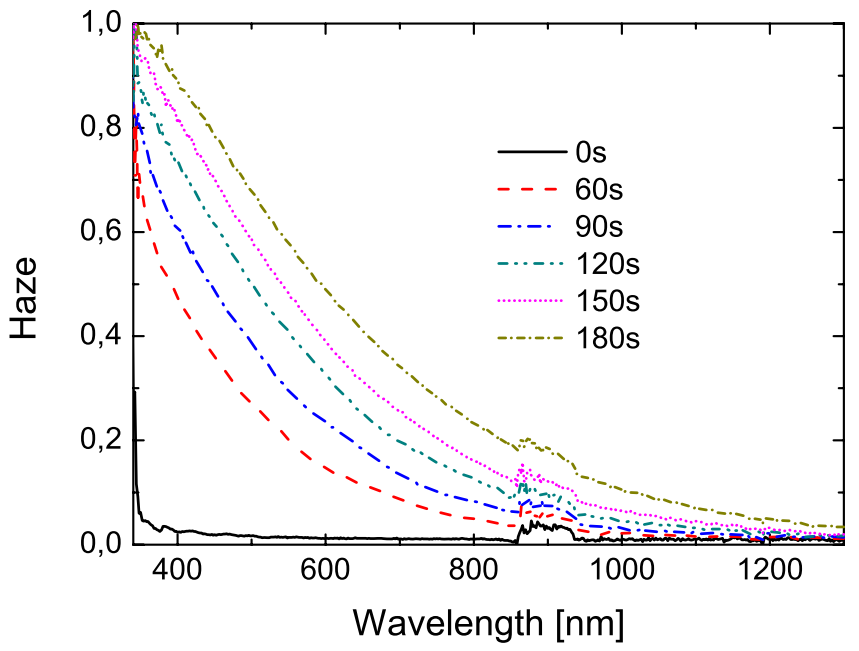

Fig. 6. Haze of high rate $\mathrm{ZnO}: \mathrm{Al}$ films deposited at $350{ }^{\circ} \mathrm{C}$ after etching in diluted HF (1\%) solution for various etching times.

Figure 6 shows haze as function of wavelength of ZnO:Al films shown in Figure 5. With increasing RMS roughness typically the haze increases. This also holds for the presented series as can be seen in Figure 6. The unetched sample exhibits nearly no haze of close to " 0 " in the whole investigated wavelength spectrum $(330 \mathrm{~nm}$ to $1300 \mathrm{~nm}$ ). For the rough surfaces the typical curve progression can be seen: For short wavelengths at around $330 \mathrm{~nm}$ the haze is close to 1 and then it decreases towards longer wavelengths. With longer etching duration the haze increases in the observed wavelength range, e.g. at $600 \mathrm{~nm}$, from $15 \%$ for the $60 \mathrm{~s}$ etched sample to $50 \%$ for the $180 \mathrm{~s}$ etched sample.

\subsection{Two-step etching first in HF solution and then in $\mathrm{HCl}$ solution}

As seen in the previous section, etching in $\mathrm{HF}$ results in a $\mathrm{ZnO}$ topography characterized by rather sharp features. This may lead to a deterioration of the fill factor of silicon thin-film solar cells [31]. Zhu et al. [37] developed a two-step etching method for high rate reactively sputtered $\mathrm{ZnO}$ :Al films. The idea is to utilize the HF etching to create the high density of craters and widen the craters by $\mathrm{HCl}$ etching. Therefore, we also employed such an etching method to our high rate $\mathrm{ZnO}$ : $\mathrm{Al}$ films prepared at $350{ }^{\circ} \mathrm{C}$. The as-grown high rate $\mathrm{ZnO}: \mathrm{Al}$ films were first etched in diluted HF solution (1\%) for $120 \mathrm{~s}$ and then in diluted $\mathrm{HCl}$ solution $(0.5 \%)$ for different etching time from $0 \mathrm{~s}$ to $16 \mathrm{~s}$. Moreover, the $\mathrm{ZnO}$ : $\mathrm{Al}$ only etched in $\mathrm{HCl}$ etching for $50 \mathrm{~s}$ is also added to this study to make a comparison for different properties.

Figure 7 shows the variations of thickness and sheet resistance as well as RMS roughness of the $\mathrm{ZnO}$ :Al films after two-step etching. As-deposited values are given at negative $x$-values, $0 \mathrm{~s}$ corresponds to the film properties after the first HF etching step. The film thickness (solid squares) is reduced by $200 \mathrm{~nm}$ by the first HF etching step (see sample "0 s"). Consequently the sheet resistance (solid circuits) increases to $9 \Omega$. The RMS roughness (solid triangles) of that sample is $\sim 80 \mathrm{~nm}$. By applying the second $\mathrm{HCl}$ etching step, the thickness is further reduced from $550 \mathrm{~nm}$ for the " $2 \mathrm{~s}$ " sample to $450 \mathrm{~nm}$ for the "16 s" sample. The sheet resistance increases from $12 \Omega$ to $18 \Omega$, respectively. The RMS roughness slightly increases up to $100 \mathrm{~nm}$ by the $\mathrm{HCl}$ etching for $2 \mathrm{~s}$. For prolonged etching in $\mathrm{HCl}$ solution (from $4 \mathrm{~s}$ to $16 \mathrm{~s}$ ) the RMS roughness keeps relatively constant. This behavior is expected for the widening effect on the craters by the $\mathrm{HCl}$, because the depth distribution would not be modified. In all HF based 


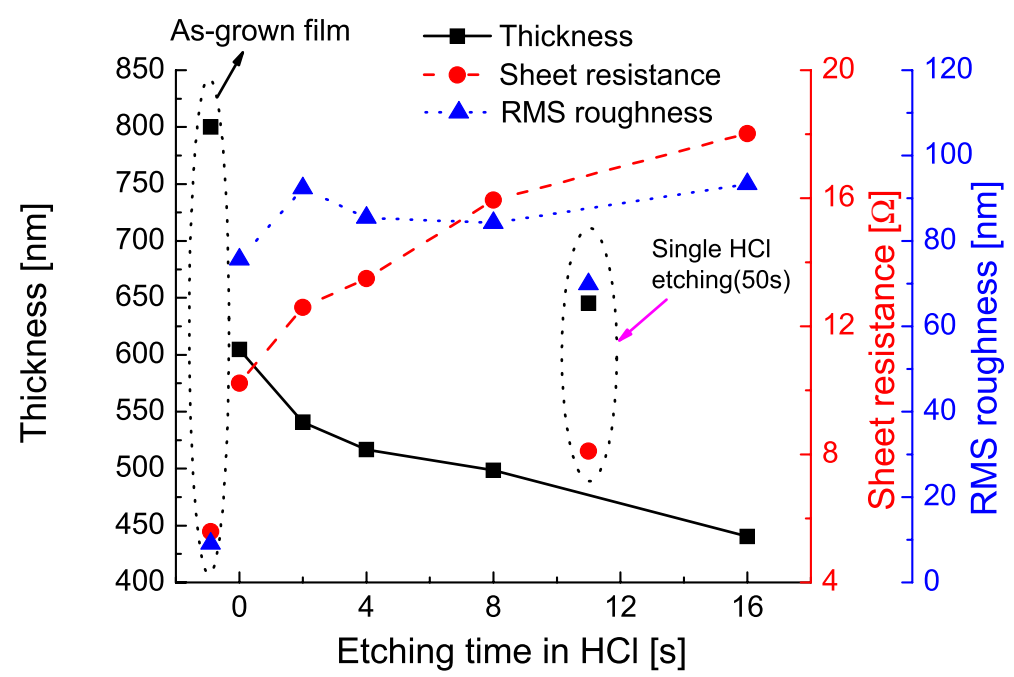

Fig. 7. The variations of thickness and sheet resistance as well as RMS roughness of high rate as-grown and after-etched ZnO:Al films from tube ceramic targets after etching with single step or two steps in $\mathrm{HF}$ etchant and $\mathrm{HCl}$ etchant.

(a)



(b)

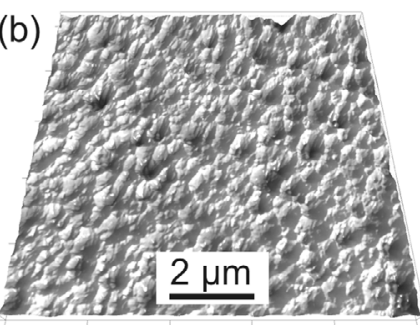

(d)

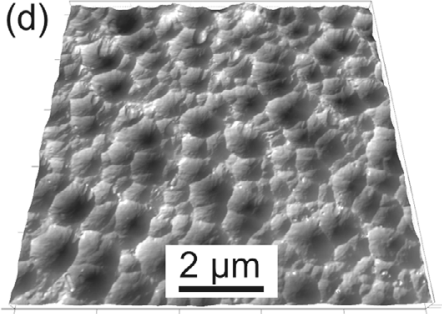

(e)

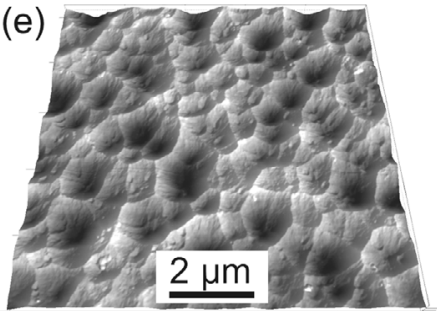

(c)



(f)

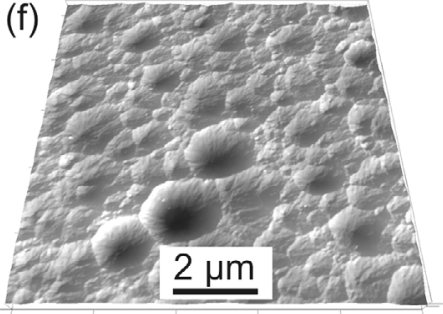

Fig. 8. The morphologies of high rate films etched with one step in HF solution or HCl solution or with two steps first in HF solution and then in $\mathrm{HCl}$ solution. The HF etching time / $\mathrm{HCl}$ etching time are: (a) $0 \mathrm{~s} / 0 \mathrm{~s}$, (b) $120 \mathrm{~s} / 0 \mathrm{~s},(\mathrm{c}) 120 \mathrm{~s} / 2 \mathrm{~s}$, (d) $120 \mathrm{~s} / 8 \mathrm{~s}$, (e) $120 \mathrm{~s} / 16 \mathrm{~s}$, (f) $0 \mathrm{~s} / 50 \mathrm{~s}$.

etch processes, the RMS roughness exceeds the value of the $\mathrm{ZnO}: \mathrm{Al}$ film etched solely in $\mathrm{HCl}$.

Figure 8 shows the topographies as given by AFM measurements of different high rate $\mathrm{ZnO}$ :Al films. Figure 8(a) shows the quite flat, unetched film surface. In Figure 8(b) shows the surface structure of $\mathrm{ZnO}$ :Al film solely etched in HF (120 s). Its surface exhibits small but steep craters with typical diameters between 100-200 nm similar to the ones observed in Figure 5 for the surface evolution upon $\mathrm{HF}$ etching. By applying a short dip in $\mathrm{HCl}$ solution, e.g. $2 \mathrm{~s}$, the crater-like features become wider (see Fig. 8(c)). With the increase of etching time in $\mathrm{HCl}(8 \mathrm{~s}$, see Fig. 8(d) and $16 \mathrm{~s}$, see Fig. 8(e)) the craters are further enlarged in diameter ending up with diameters around to $1-2 \mu \mathrm{m}$ for the longest applied etching time. This topography, as shown in Figure 8(e) looks similar to type B [15] that is favored for solar cell application. For comparison the rather flat surface of a film etched in $\mathrm{HCl}$ for $50 \mathrm{~s}$ is shown in Figure 8(f), which typically leads to reduced short circuit currents and consequently low efficiencies [17]. For reactively sputtered ZnO:Al films a similar etching behavior was observed as well [37].

All ZnO:Al films of this two-step etch series show high transmission of more than $85 \%$ and low absorption of less than $5 \%$ in visible spectrum region (see Fig. 9(a)). Even in the infrared spectrum region, they all show high transmission and low absorption due to low carrier concentration shown in Figure 1. The slight variations of transmission 

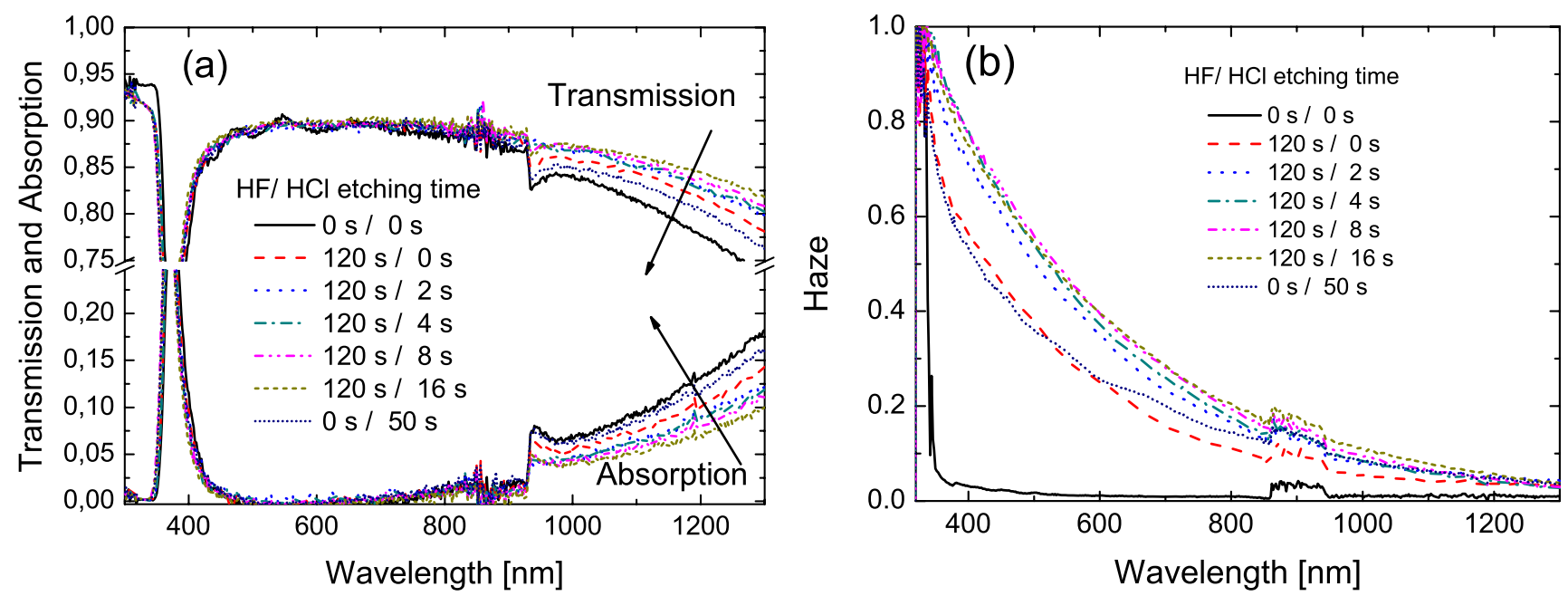

Fig. 9. The transmission and absorption (a) as well as the haze (b) of high rate films etched with one step in HF solution or $\mathrm{HCl}$ solution or with two steps first in $\mathrm{HF}$ solution and then in $\mathrm{HCl}$ solution. etch times are given in the legend.

and absorption are mainly due to the change in thicknesses of films etched for different etching times. The haze is illustrated in Figure 9(b). For comparison the curve of a film etched in $\mathrm{HCl}$ is also plotted. Even though the surfaces of the solely $\mathrm{HCl}$ and $\mathrm{HF}$ etched samples (compare Figs. 8(b) and 8(f), respectively) are significantly different in number, size and shape of their features, the haze of both samples is similar. At $600 \mathrm{~nm}$ the haze of both samples is about 0,25. By dipping the HF etched sample into $\mathrm{HCl}$ acid solution for short time $(2 \mathrm{~s})$, the haze of the sample increases in the whole observed wavelength range, e.g. it is 0,4 at $600 \mathrm{~nm}$. By prolonging the etching time in the $\mathrm{HCl}$ solution to $4 \mathrm{~s}$ the haze only slightly increases and stays almost constant for longer etching times (8 or $16 \mathrm{~s}$ ).

\section{Conclusions}

In this study, the etching behaviour of high rate $\mathrm{ZnO}$ :Al films deposited at substrate temperatures in the range of $250-350{ }^{\circ} \mathrm{C}$ in $\mathrm{HCl}$ and $\mathrm{HF}$ was compared. For films deposited at lower substrate temperatures all films show a rather flat surface topography after etching in both etchants. $\mathrm{ZnO}$ : Al films deposited at $350{ }^{\circ} \mathrm{C}$ and $325^{\circ} \mathrm{C}$ display characteristic surface structures with either regular small or a few large craters after etching in $\mathrm{HF}$ or $\mathrm{HCl}$, respectively. In contrast to findings for optimized low deposition rate $\mathrm{ZnO}$ :Al films [8], prolonged etching does not create regularly distributed large craters by single step etching for our high rate sputtered $\mathrm{ZnO}$ :Al films. Combining both etching first in $\mathrm{HF}$ and then in $\mathrm{HCl}$ leads to regular large crater distribution on the surface of $\mathrm{ZnO}: \mathrm{Al}$ films with strong and efficient light scattering that are in favor of light trapping in solar cells. Still the deposition of $\mathrm{ZnO}$ :Al films at high substrate temperatures $\left(>300{ }^{\circ} \mathrm{C}\right)$ is required to result in highly conductive and highly transparent TCO films with compact structure at the same time to form craters upon etching.
$\mathrm{ZnO}: \mathrm{Al}$ films with regular distribution of large craters on their surfaces have been achieved previously on reactively sputtered high rate $\mathrm{ZnO}$ : Al films etched with such a two-step etching method and proven to result in excellent silicon thin film solar cell performance [37]. However, the etching rate of films here is higher than reactively sputtered films, which could be explained by higher working pressure in our case. Thus the resistance of the films is a bit higher than in the other study, but others reported that sheet resistance well above $10 \mathrm{Ohm}$ is still sufficient and might even be favorable for solar cells, since the free carrier absorption is reduced in these films [38,39].

The authors would like to thank H. Siekmann, J. Worbs, and H.-P. Bochem for extensive technical support. Financial support by the German BMU (contract No. 0327693A) and by the European Commission (contract No. 019670) is gratefully acknowledged. The authors also thank the company W. C. Heraeus for providing the targets.

\section{References}

1. S. Besbes, H. Ben Ouada, J. Davenas, L. Ponsonnet, N. Jaffrezic, P. Alcouffe, Materials Science \& Engineering C-Biomimetic and Supramolecular Systems 26, 505 (2006)

2. H. Kim, A. Pique, J.S. Horwitz, H. Mattoussi, H. Murata, Z.H. Kafafi, D.B. Chrisey, Appl. Phys. Lett. 74, 3444 (1999)

3. C.A. Wang, S.A. VanSlyke, Appl. Phys. Lett. 51, 913 (1987)

4. Y. Akao, T. Haranoh, Transparent conductive coatings for flat panel displays (Elsevier Science Bv, Amsterdam, 1999)

5. W.J. Lee, Y.K. Fang, J.J. Ho, C.Y. Chen, R.Y. Tsai, D.Y. Huang, F.C. Ho, H.W. Chou, C.C. Chen, J. Elect. Mat. 31, 129 (2002)

6. B. Rech, O. Kluth, T. Repmann, T. Roschek, J. Springer, J. Müller, F. Finger, H. Stiebig, H. Wagner, Sol. Energy Mat. Sol. Cells 74, 439 (2002) 
7. E. Fortunato, D. Ginley, H. Hosono, D.C. Paine, Mrs Bulletin 32, 242 (2007)

8. B. Rech, T. Repmann, M.N. van den Donker, M. Berginski, T. Kilper, J. Hupkes, S. Calnan, H. Stiebig, S. Wieder, Thin Solid Films 511, 548 (2006)

9. S. Calnan, J. Hupkes, B. Rech, H. Siekmann, A. Tiwari, Thin Solid Films 516, 1242 (2008)

10. M. Berginski, J. Hüpkes, M. Schulte, G. Schöpe, H. Stiebig, B. Rech, M. Wuttig, J. Appl. Phys. 101, 11 (2007)

11. M. Kondo, A. Matsuda, Thin Solid Films 457, 97 (2004)

12. M. Kondo, T. Matsui, Y. Nasuno, H. Sonobe, S. Shimizu, Thin Solid Films 501, 243 (2006)

13. S. Faÿ, L. Feitknecht, R. Schluchter, U. Kroll, E. VallatSauvain, A. Shah, Sol. Energy Mat. Sol. Cells 90, 2960 (2006)

14. J. Hüpkes, B. Rech, O. Kluth, T. Repmann, B. Zwaygardt, J. Müller, R. Drese, M. Wuttig, Solar Energy Mat. Sol. Cells 90, 3054 (2006)

15. O. Kluth, G. Schöpe, J. Hüpkes, C. Agashe, J. Müller, B. Rech, Thin Solid Films 442, 80 (2003)

16. H. Zhu, E. Bunte, J. Hüpkes, H. Siekmann, S.M. Huang, Thin Solid Films 517, 3161 (2009)

17. E. Bunte, H. Zhu, J. Hüpkes, 23rd European Photovoltaic Solar Energy Conference, Valencia, Spain, 2008, p. 2105

18. J.I. Owen, J. Hüpkes, H. Zhu, E. Bunte, S.E. Pust, Physica Status Solidi (A) 208, 109 (2010)

19. T. Minami, H. Nanto, S. Takata, Japanese J. Appl. Phys. Part 2-Lett. 23, L280 (1984)

20. T. Minami, H. Nanto, S. Takata, Appl. Phys. Lett. 41, 958 (1982)

21. R.L. Petritz, Phys. Rev. 104, 1508 (1956)

22. K.L. Chopra, S. Major, D.K. Pandya, Thin Solid Films 102, 1 (1983)

23. J.W. Orton, M.J. Powell, Rep. Progress Phys. 43, 1263 (1980)
24. K. Ellmer, R. Mientus, Thin Solid Films 516, 4620 (2008)

25. T. Minami, H. Sato, H. Nanto, S. Takata, Japanese J. Appl. Phys. Part 2-Lett. 24, L781 (1985)

26. K. Tominaga, K. Kuroda, O. Tada, Japanese J. Appl. Phys. Part 1-Regular Papers Short Notes \& Review Papers 27, 1176 (1988)

27. T. Minami, H. Sato, T. Sonoda, H. Nanto, S. Takata, Thin Solid Films 171, 307 (1989)

28. K. Ellmer, J. Phys. D-Appl. Phys. 34, 3097 (2001)

29. F. Ruske, A. Pflug, V. Sittinger, B. Szyszka, D. Greiner, B. Rech, Thin Solid Films 518, 1289 (2009)

30. D. D. Perrin, Ionization Constants of Inorganic Acids and Bases in Aqueous Solution, 2nd. (Pergamon, Oxford, 1982)

31. H. Zhu, J. Hüpkes, E. Bunte, A. Gerber, S.M. Huang, Thin Solid Films 518, 4997 (2010)

32. J. Hüpkes, B. Rech, S. Calnan, O. Kluth, U. Zastrow, H. Siekmann, M. Wuttig, Thin Solid Films 502, 286 (2006)

33. J. Hüpkes, B. Rech, O. Kluth, J. Müller, H. Siekmann, C. Agashe, H.P. Bochem, M. Wuttig, in Amorphous and Nanocrystalline Silicon-Based Films-2003, edited by J.R. Abelson, G. Ganguly, H. Matsumura, J. Robertson, E.A. Schiff, 762, 405 (2003)

34. V. Sittinger, F. Ruske, W. Werner, B. Szyszka, B. Rech, J. Hupkes, G. Schope, H. Stiebig, Thin Solid Films 496, $16(2006)$

35. H. Zhu, E. Bunte, J. Hüpkes, S.M. Huang, Thin Solid Films 519, $2366(2011)$

36. R.J. Hong, X. Jiang, B. Szyszka, V. Sittinger, S.H. Xu, W. Werner, G. Heide, J. Crystal Growth 253, 117 (2003)

37. H. Zhu, J. Hüpkes, E. Bunte, J. Owen, S.M. Huang, Sol. Energy Mat. Sol. Cells 95, 964 (2011)

38. S. Faÿ, J. Steinhauser, N. Oliveira, E. Vallat-Sauvain, C. Ballif, Thin Solid Films 515, 8558 (2007)

39. M. Berginski, J. Hüpkes, W. Reetz, B. Rech, M. Wuttig, Thin Solid Films 516, 5836 (2008) 